
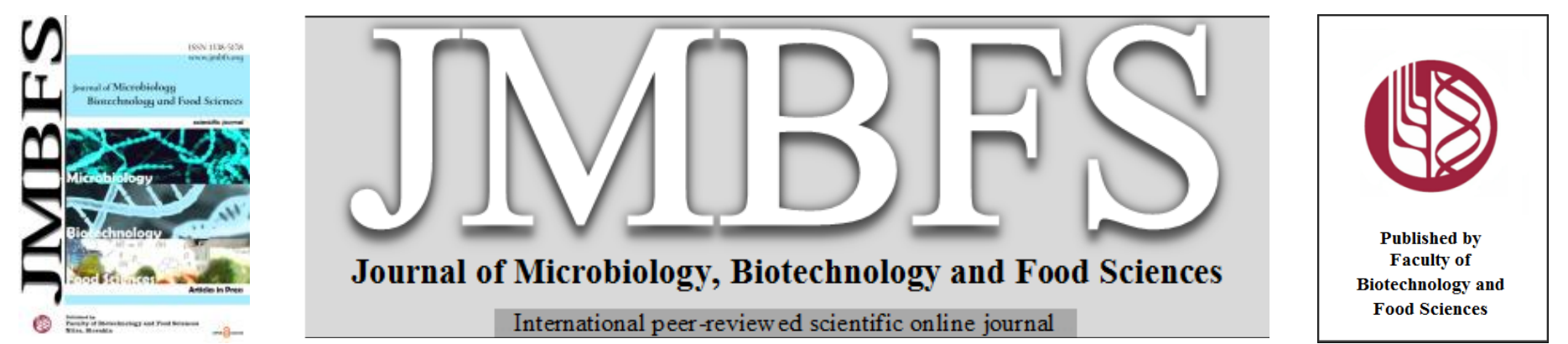

\title{
CLASSIFICATION AND MECHANISM OF BACTERIOCIN INDUCED CELL DEATH: A REVIEW
}

\author{
Kajal Sharma ${ }^{1}$, Sandeep Kaur ${ }^{2}$, Rajat Singh ${ }^{3}$ and Naveen Kumar ${ }^{4 *}$
}

Address(es): Dr Naveen Kumar, Assistant Professor, Amity Institute of Biotechnology, Amity University Rajasthan, Jaipur, India, 303002

${ }^{1}$ Department of Life Sciences, Guru Kashi University, Bathinda, Punjab, India.

${ }^{2}$ Department of Life Sciences, RIMT University, Mandi Gobindgarh, Pb, India.

${ }^{3}$ School of Applied and Life Sciences, Uttaranchal University, Dehradun, India-248007.

${ }^{4}$ Amity Institute of Biotechnology, Amity University Rajasthan, Jaipur, India, 303002.

*Corresponding author: nkft87@gmail.com

https://doi.org/10.15414/jmbfs.3733

\section{ARTICLE INFO}

Received 20. 9. 2020

Revised 30. 6. 2021

Accepted 1.7. 2021

Published 1. 12. 2021

Regular article

OPEN $\partial_{\text {ACCESS }}$

\begin{abstract}
Multidrug resistance and toxicity associated with antimicrobial agents among pathogenic bacteria leading to a surge in morbidity and mortality in humans need bold proclamation in the area of research and development of new biological agents. The maximum propitious possibility we can see in the area of bacteriocins. Bacteriocins are ribosomally synthesized peptides produced by gram-positive and gramnegative bacteria which evince wide and narrow antimicrobial activity spectrum. They can survive in a highly competitive microbial environment. Bacteriocins attack their targeted bacterial cells through different mechanisms. Understanding different mechanisms that induced cell death will enable researchers to develop methodologies to limit this life-threatening problem. Therefore, in this study, we provide the updated information on the number of bacteriocins produced, their potential producers and different mode of action against relevant pathogenic bacteria.
\end{abstract}

Keywords: Antimicrobial, toxicity, bacteriocins, mechanisms, pathogenic bacteria

\section{INTRODUCTION}

Today, the world suffers from a number of infectious diseases, which are mainly caused by pathogenic organisms. Pathogenic organisms inhibit the production of antimicrobial peptides inside the body and caused several life-threatening diseases (Sharma et al., 2016; Singh et al., 2021). The important part of natural immunity in human is the production of antimicrobial peptides which protects various disease-causing organisms like bacteria, fungi, yeast viruses and cancer cells (Reddy et al., 2004; Kaushik et al., 2017). Bacteria itself release some antimicrobial peptides which are the biologically extra-cellular product of ribosomal synthesis (Klaenhammer, 1993; Pirzada et al., 2004). They are produced by both gram-positive and gram-negative bacteria including some archaea (Zheng et al., 2015). A large portion of bacteriocins from gram-negative bacteria resembles defensins which are the eukaryotic antimicrobial peptides (Baindara et al., 2018). Many bacteria are known for producing bacteriocins in humans, plants and various food products where they have a valuable place e.g. $E$. coli, Lactic acid bacteria (LAB), Weissellaconfusa, Streptococcus mutans, Streptococcus salivarius, Bacillus subtilis etc. Out of which LAB described as GRAS (generally regarded as safe) for human consumption (Balciunas et al., 2013; Kaushik and Arora, 2017; Indumathi et al. 2015; Sing, 2021). The bacteriocins show inhibitory action on food deterioration and foodborne pathogenic microorganisms, additionally, the bacteriocins from lactic acid microorganisms widely known for both food preservative and therapeutic potentials (Kumari et al., 2018; Mittal et al., 2020, Sharma et al., 2016). Bacteriocins from different species of bacteria, in contrast to all other antibiotics, show killing action on the same or closely related species (Peter R, 1965). Each species of bacteria produces tens or even hundreds of different kinds of bacteriocins (Bindiya et al., 2016). Bacteriocins are a heterogeneous group of particles with different morphological and biochemical entities. They range from simple and low molecular weight protein to complex and high molecular weight protein. Moreover, the bacteriocins are non-immunogenic, biodegradable substances and possess cancer-cell specific toxicity (Kaur et al., 2015). They also act as the competitive agents between the microbial communities (Chao $\boldsymbol{e t}$ al., 1981, Majeed et al., 2013, Riley et al., 1999). Researchers had conducted a deep study on various aspects of bacteriocins like the methods for their detection, characterization, purification and identification of genetic determinants from gram-positive and gram-negative micro-organisms (Catherine et al., 1993).

\section{BACKGROUND OF THE REVIEW}

Colicin is the very first bacteriocin discovered by Belgian scientist Gratia, (1925) a heat-liable product where he observed that Escherichia coli V inhibits Escherichia coli $\mathrm{S}$ during his search for the ways to kill the bacteria. The inhibition of one bacterial strain by another had been observed many times by Gratia. But the importance of bacteriocin can't explore much at that time due to the lack of knowledge about its structure and production which led to the dominance of chemically synthesized broad-spectrum antibiotics (Syngulon.com). Fredericq, (1946) revealed the proteinaceous nature of colicin and demonstrated that the inhibitory activity of bacteriocin was due to the presence of specific surface receptors of sensitive cells. After a long period, it is verified that a large number of bacteria produced some common molecules which inhibit the growth of other strains or species, these molecules were named bacteriocins (Jacob et al., 1953). Bacteriocins have been detected in all major lineages of eubacteria and some members of Archaebacteria and recently it becomes a viable alternative to conventional antibiotics (Torrebranca et al., 1995; Gillor et al., 2008; Cotter et al., 2013).

\section{CLASSIFICATION OF BACTERIOCINS}

Bacteriocins can be classified based on their molecular weight, thermostability, enzymatic sensitivity, mode of action and presence of post-translationally modified amino acids (Klaenhammer, 1993). Jack et al. (1995) reported that the presence of the number of disulfide and monosulfide (lanthione) bonds not only forms the basis of classification but also affects the activity spectrum of bacteriocins. Furthermore, based on molecular weight gram-negative bacteria are divided into two classes namely colicins and microcins. Most bacteriocins of gram-negative bacteria are isolated from E. coli and other enterobacteria (Hassan et al., 2012) The bacteriocins of gram-positive bacteria are divided into four classes (Class I, II, III, IV) which are broadly described in previous literature. These classes from gram-negative and gram-positive bacteria are further subdivided into their respective sub-groups (Ramu $\boldsymbol{e t}$ al., 2015). However, Cotter et al. classified the 
bacteriocin produced from LAB (gram-positive bacteria) into two main classes, lantibiotics (class I), not containing lanthionine lantibiotics (class II) whereas class III was individually designated as bacteriolysins. It was also suggested by the authors that class IV should be extinguished (Tumbarski et al., 2018). So, recently authors have altered the classification of gram-positive bacteria from four classes to three, while different authors have used a somewhat different description of subclasses (Mokoena, 2017). Yang et al. (2014) mentioned that microcin E492 derived from gram-negative bacterial sp. Klebsiella pneumonia, so class II should be categorized under microcins of gram-negative bacteria. Moreover, the bacteriocins are currently used in agro-food as a food preservative however it may be considered as potential candidates for further development and used in health contexts. The different classification and applications of bacteriocins are enlisted in Figure 1 and 2
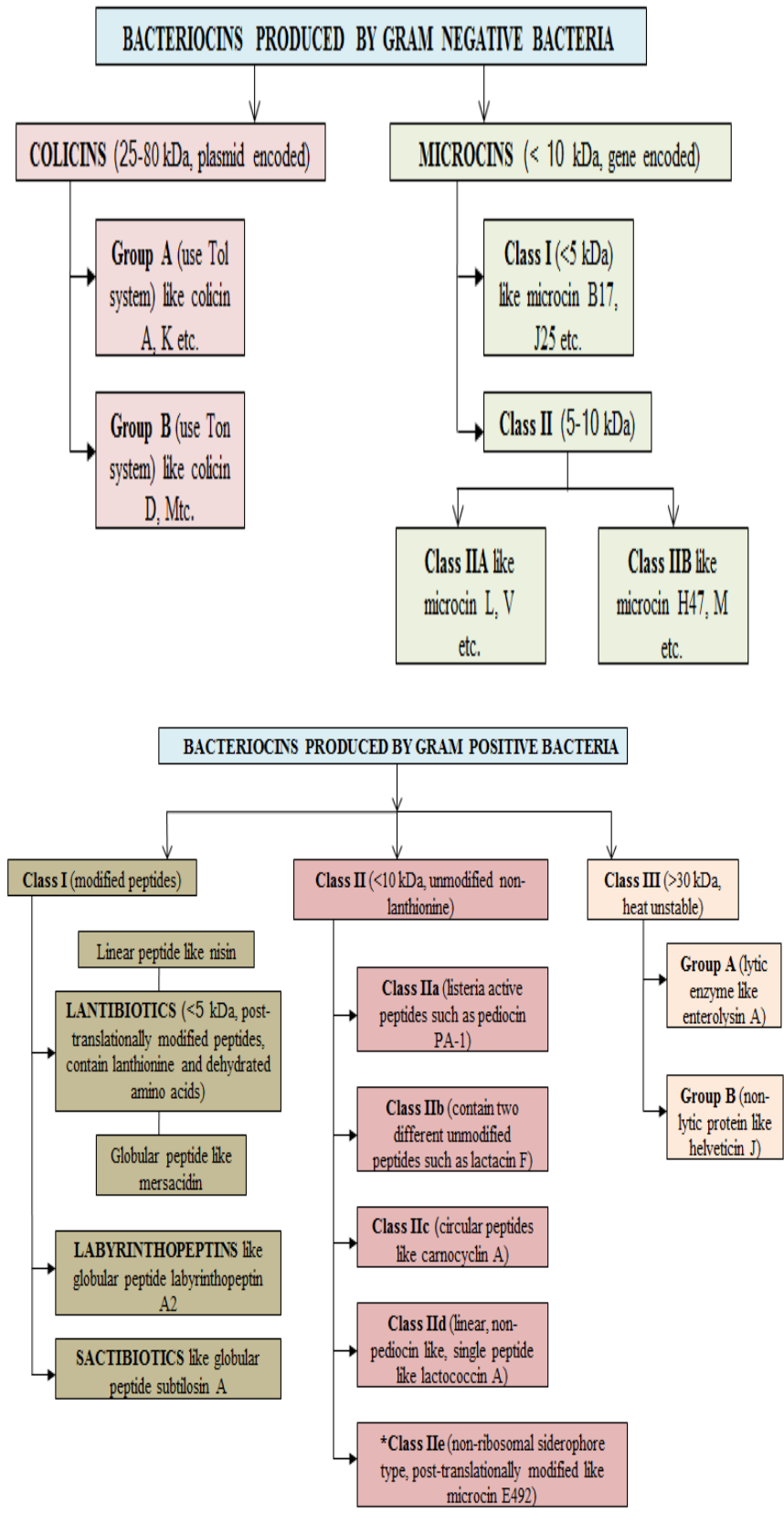

Figure 1 Classification of gram-negative and gram-positive bacteriocins (Yang et al., 2014)

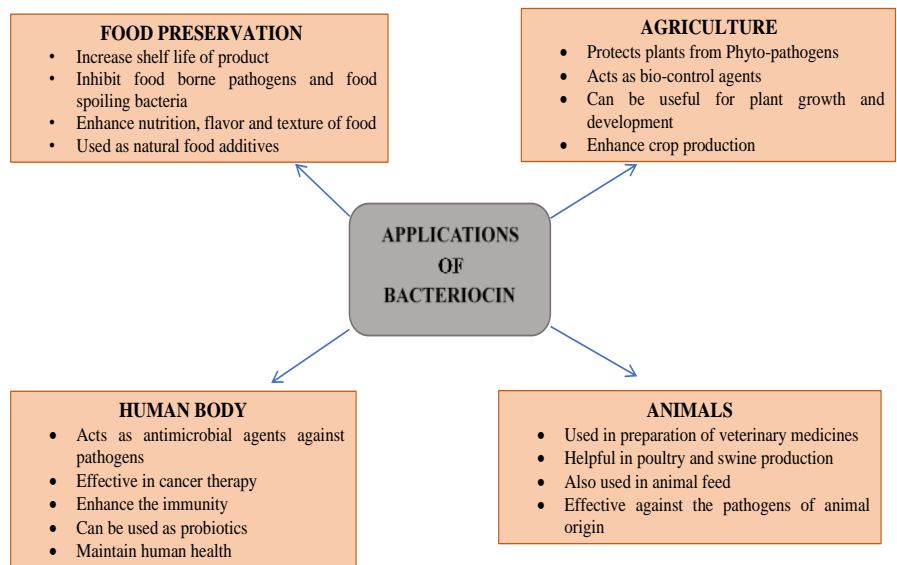

Figure 2 Schematic representation of various applications of bacteriocins in different sectors

\section{PROPERTIES OF BACTERIOCIN FOR INHIBITION}

Bacteriocins have some special features which make them lethal towards pathogenic organisms. They must have a cationic (mostly at $\mathrm{pH}$ 7.0) and highly hydrophobic nature to be lethal as observed for the most bacteriocins belonged to Class I and II. They must be active at a wide range of $\mathrm{pH}$, as found in the case of numerous small size bacteriocins where they show antibacterial activity at different $\mathrm{pH}$ ranging from 3.0 to 9.0. Their high isoelectric point promotes the interaction at physiological $\mathrm{pH}$ with the anionic surface of bacterial membranes which cause the insertion of hydrophobic moiety into the bacterial membrane which finally build up a trans-membrane pore that led to cell death due to gradient dissipation (Jack et al., 1995). They are diffusible toxins that do not require contact between bacteria like type six secretion system (T6SS) and contact-dependent inhibition (CDI) (Sharp et al., 2017). Bacteriocins are potent even at the pico to nanomolar concentration as compared to eukaryotic AMPs which acts at a micromolar concentration (Hassan et al., 2012). Low molecular protein must be heat stable to show the killing action on related pathogenic strains. The stabilization of secondary structures accompanies by the complex pattern of monosulfide and disulfide intramolecular bonds which acts to reduce the number of possible unfolded structures (entropic effect) (Oscáriz et al., 2001, Singh et al., 2013). However, the presence of some enzymes like proteinase K, trypsin, proteases, pronase and other proteolytic enzymes inhibitor may lead to the complete reduction of the killing action of bacteriocins produced by different bacterial species (Sharma et al., 2009; Jabeen et al., 2009; Pirzada et al., 2004; Todorov and Dicks, 2005; Tolincki et al., 2010). The way, they kill the sensitive cells is called"quantal" killing rather than "molar" cooperative killing action of classical antibiotics (Mayr-Harting et al., 1972).

\section{MECHANISMS OF BACTERIOCINS}

Bacteriocins kill the pathogenic bacteria in several ways, like pore-forming inhibition of cell wall, nucleic acid and protein synthesis (Figure 3). Usually, they have a narrow killing spectrum as they are limited to the inhibition of closely related species and simultaneously they may have broad-spectrum activity against distantly related bacterial species (Singh et al., 2013; Klaenhammer, 1993; Adams and Moss, 2008; Kumariya et al., 2019) and plays a defensive role by inhibiting the invasion of other strains or by limiting the growth of neighbouring cells (Riley and Wertz, 2002b). The production of bacteriocins seems to be a hereditary feature associated with cytoplasmic genes i.e. bacteriocinogenic factors. Their mode of action varies greatly from one species to another (Daw and Falkiner, 1996). 


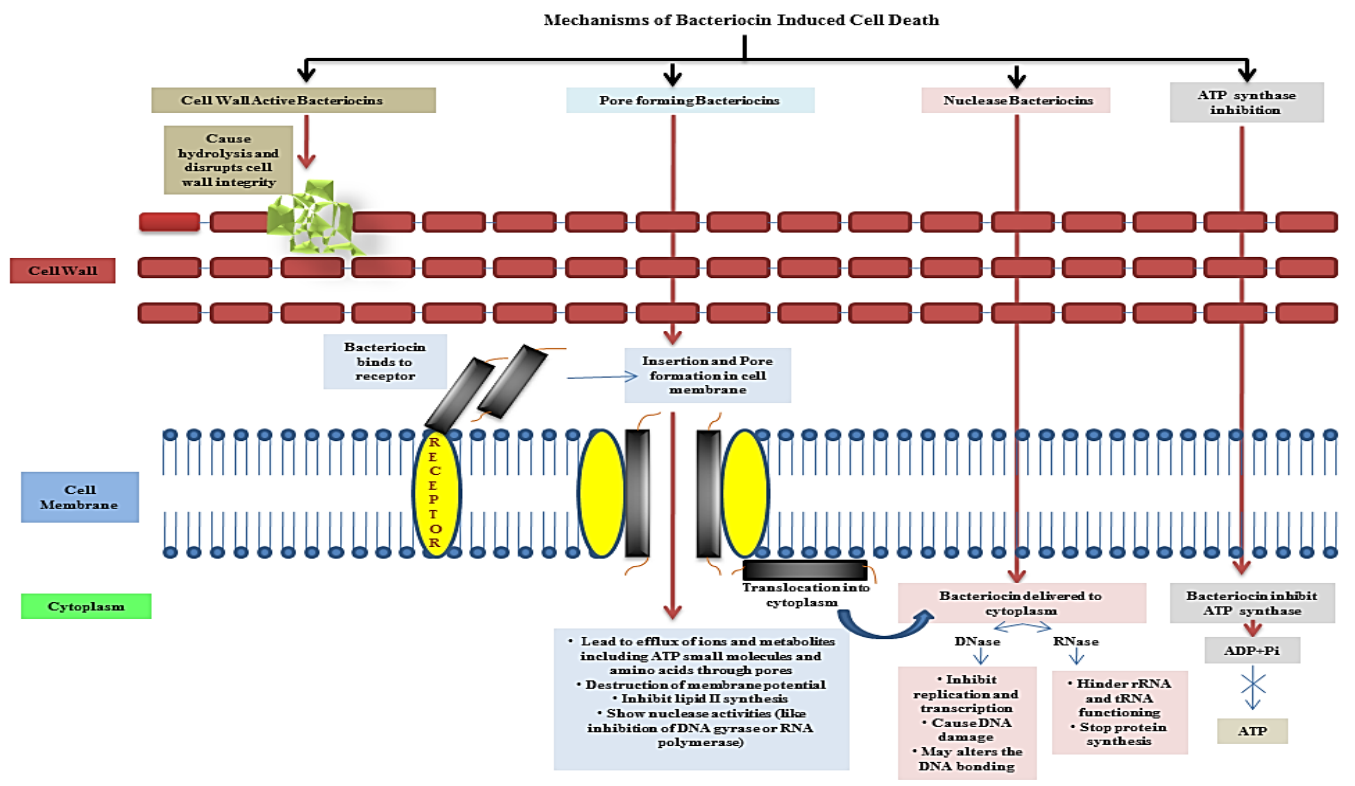

Figure 3 Schematic diagram of mechanisms of bacteriocin induced cell death

\section{INHIBITION BY PORE FORMATION}

Pore formation is the well-known mechanism in which these antibacterial proteins binds to the specific receptors on cells and forms pores in the membrane which is also called as cell permeability and thus cause the death of pathogenic microorganism (Preciado et al., 2016). These antibacterial proteins are also called c PFTs are one of the wide categories of virulence factors as they constitute 25 $30 \%$ of cytotoxic bacterial proteins (Alouf, 2003; Gonzalez et al., 2008). The diameter of the pore formed by these proteins varies from one species to another, ranging between 1-50 nm consisting of 6-50 or more units of PFPs (Peraro and van der Goot, 2016). The largest pores found in cholesterol-dependent cytolysins (CDCs) whose diameter ranges from $25-40 \mathrm{~nm}$ (Twetenet al., 2015). Generally, PFPs are genetically encoded large proteins ( $\alpha$-toxin) or small cationic peptides which are delivered to the targeted cell for production and insertion into the membrane (Panchal et al., 2002). Based on the secondary structure of the region that allows the formation of the pore by penetrating the host cell, PFPs are divided into two main classes: $\alpha$-PFPs and $\beta$-PFPs which forms pores by bundles of $\alpha$ helicals or by trans-membrane $\beta$-barrels respectively (Anderluhet al., 2008, Ostolazaet al., 2019). These antibacterial proteins are water-soluble monomer that bind to the lipid membrane of the cell and oligomerize to form structural assemblies called pre-pores. These pre-pores exposed the hydrophobic surface of the cell by undergoing some conformational changes that lead to the insertion into the lipid bilayer which forms a pore that causes the permeabilization of the cell membrane (Omersa et al., 2019). This mechanism is followed by $\beta$-PFPs while in the case of $\alpha$-PFPs the insertion into the membrane is associated with a sequential oligomerization which then forms a partial or complete pore and the pore remains active in both cases. The $\beta$-pores are structurally more stable in comparison to $\alpha$ pores due to the inter-chain interactions between the hydrogen bonds (Ostolazae al., 2019). The formation of oligomers is a common characteristic of PFPs that pierce the cell membrane of the pathogen (Cosentino et al., 2016). Pore-forming proteins disrupt the maintenance of the osmotic balance of the cell which leads to the cytolysis (Alouf, 2003). They make the path for the passage of ions, proteins or other constitutes through the targeted membrane. The loss of potassium and magnesium ion has been implicated as the primary cause of cell death (Konisky, 1982). Pore formation also causes rapid dissipation of transmembrane electrostatic potential which lead to the rapid death of bacterial cells (Prince et al., 2016).

Nisin belongs to the lantibiotic family, an amphiphilic and cationic bacteriocin (3.4kDa) isolated from the different strains of Lactococcus lactis subsp. lactis, is one of the widely studied bacteriocins. It is an FDA approved and GRAS peptide with recognized potential for clinical use (Shin et al., 2016). It acts on the targeted cells through pore formation by the use of "Docking Molecule" mediated by cell wall precursor lipid II which forms stable pores of around 2-2.5 nm diameter (Wiedemann et al., 2004). Nisin binds to lipid II with the two lanthionine rings at the N-terminus, forming a pyrophosphate cage around the head group of lipid II and flexible hinge region cause the insertion of $\mathrm{C}$-terminus in a transmembrane orientation which led to the formation of a stable pore (Prince et al., 2016). Kraaij et al., (1998) demonstrated the importance of translocation of the $\mathrm{C}$-terminal region in pore formation. However, the C- terminus of NisI (immunity protein of Lactococcus lactis) found to inhibiting the nisin mediated pore formation by protecting the lipid II (Alkhatib et al., 2014). Further, nisin use all lipid II molecules to form the pore complex which uniformly consists of 8 nisin and 4 lipid-II molecules. These pores were able to resist the solubilization of the membrane environment by mild detergents (Hasperet al., 2004). The micromolar concentrations are necessary in the absence of lipid II while nanomolar concentrations are sufficient to form a pore in the presence of lipid II (Christ 2007). Nisin also acts as an anionic selective carrier during the absence of anionic membrane phospholipids and forms nonselective, wedge-like, multistate, waterfilled pores in the presence of anionic phospholipids which results from the bending of lipid surface due to co-insertion of the surface-bound aggregate to it (Moll et al., 1996). The bacteriocins that kill the pathogens by pore formation are enlist in Table 1.

\section{CELL WALL BIOSYNTHESIS INHIBITION}

The antimicrobial peptides involved in the inhibition of biosynthesis of cell wall either by inhibiting peptidoglycan synthesis or by binding to the lipid II or may impair the cell wall functions are called as cell-wall active or membrane-active bacteriocins. This mechanism may involve a concerted action with pore formation as observed in nisin, a well-known bacteriocin widely used in food preservation. This mechanism is followed by both gram-negative and gram-positive bacteria. It comprises a wide variety of structures like lipid II-binding bacteriocins, two peptide lantibiotics and non-modified bacteriocins (Roceset al., 2012). In eukaryotic cells, cell membrane acts as the main target of bacteriocins where they enhance the expression of negatively charged cell surface molecules on the cancer cells makes them prone to the cytotoxic activity of bacteriocins (Kaur et al., 2015). Nisin is the first example of a membrane-targeted lantibiotics (Breukinket al. 2003). However, Tol et al. (2015) suggested that nisin variants that cluster lipid II kill L-form bacteria without involving the delocalization of peptidoglycan synthesis which is the primary killing mechanism of these lantibiotics. Lactococcin 972 (Lcn972) is the first unmodified, bacteriocin that binds to the cell wall precursor lipid II to inhibit the septum biosynthesis in Lactococcus lactis (Martínez et al., 2008). Scherer et al., (2015) revealed that an increase in the size of the nisin-lipid-II complex also plays a role in the inhibition of cell wall synthesis and also induce vesicle budding in the targeted cell membrane. However in some cases, the destabilization of the cell wall or outer membrane is brought by stress condition such as treatment of targeted cell with chemicals or by inducing some physical stress conditions like $\mathrm{pH}$, heating, freezing etc., which may increase the sensitivity of targeted cell as observed for gram-negative bacteria (Costa $\boldsymbol{e t}$ al . 2019). Besides all this, plantaricin $\mathrm{NC} 8$, a two-peptide non-lantibiotic class IIb bacteriocin composed of PLNC8 $\alpha$ and PLNC $8 \beta$ and derived from Lactobacillus plantarum ZJ316 has been found to show antimicrobial activity against Micrococcus luteus 1.193 by following the mechanism of cell membrane disruption without targeting lipid II (Jiang et al., 2018). The bacteriocins that follow the cell wall inhibition mechanism for killing of pathogens are listed in Table 2. 
Table 1 List of some bacteriocins that kill the pathogens by pore formation

Name of the

bacteriocin

Acanthaporin

Pentocin MQ1

Acanthamoeba culbertsoni

Lactobacillus pentosus CS2

$\mathrm{PmnH}$

Pseudomonas species
Producing microorganism

Inhibition spectrum

Cytotoxic for human neuronal cells, antibacterial against various bacterial strains

Potent against $M$. luteus, $B$. cereus and

L.monocytogenes, exhibit high chemical, thermal and $\mathrm{pH}$ stability but sensitive to proteolytic enzymes

Reflects parasitism of the ferrichrome type transporter for the entry into targeted cells under iron-limited growth conditions

Antibacterial against gram-positive bacteria, poten against gram-negative bacteria when used at high concentration or when targeted cell have been pretreated with EDTA, also active against sporeforming bacteria

Nisin $(3.5 \mathrm{kDa}) \quad$ Lactococcus lactis

\begin{tabular}{|c|c|}
\hline Ruminococcin C & RuminococcusgnavusE1 \\
\hline Acidophilin 801 & $\begin{array}{l}\text { Lactobacillus acidophilus IBB } \\
801\end{array}$ \\
\hline Cytolysin A & $\begin{array}{l}\text { Escherichia coli (pathogenic } \\
\text { strain) }\end{array}$ \\
\hline Microcin E492 & Klebsiella pneumonia RYC492 \\
\hline Lacticin Q & Lactococcus lactis QU5 \\
\hline Lacticin 3147 & $\begin{array}{l}\text { Lactococcus lactis subsp. lactis } \\
\text { DPC } 3147\end{array}$ \\
\hline Pediocin PA-1 & $\begin{array}{l}\text { Pediococcusacidilactici } \\
\text { PAC } 1.0\end{array}$ \\
\hline Lactococcin $\mathrm{G}$ & Lactococcus sp. \\
\hline Acidocin J1132 & $\begin{array}{l}\text { Lactobacillus acidophilus JCM } \\
1132\end{array}$ \\
\hline Thermophilin 13 & Streptococcus thermophilus \\
\hline $\begin{array}{l}\text { Bacteriocin AS-48 } \\
\text { (Enterocin AS-48) }\end{array}$ & Enterococcus faecalis \\
\hline
\end{tabular}

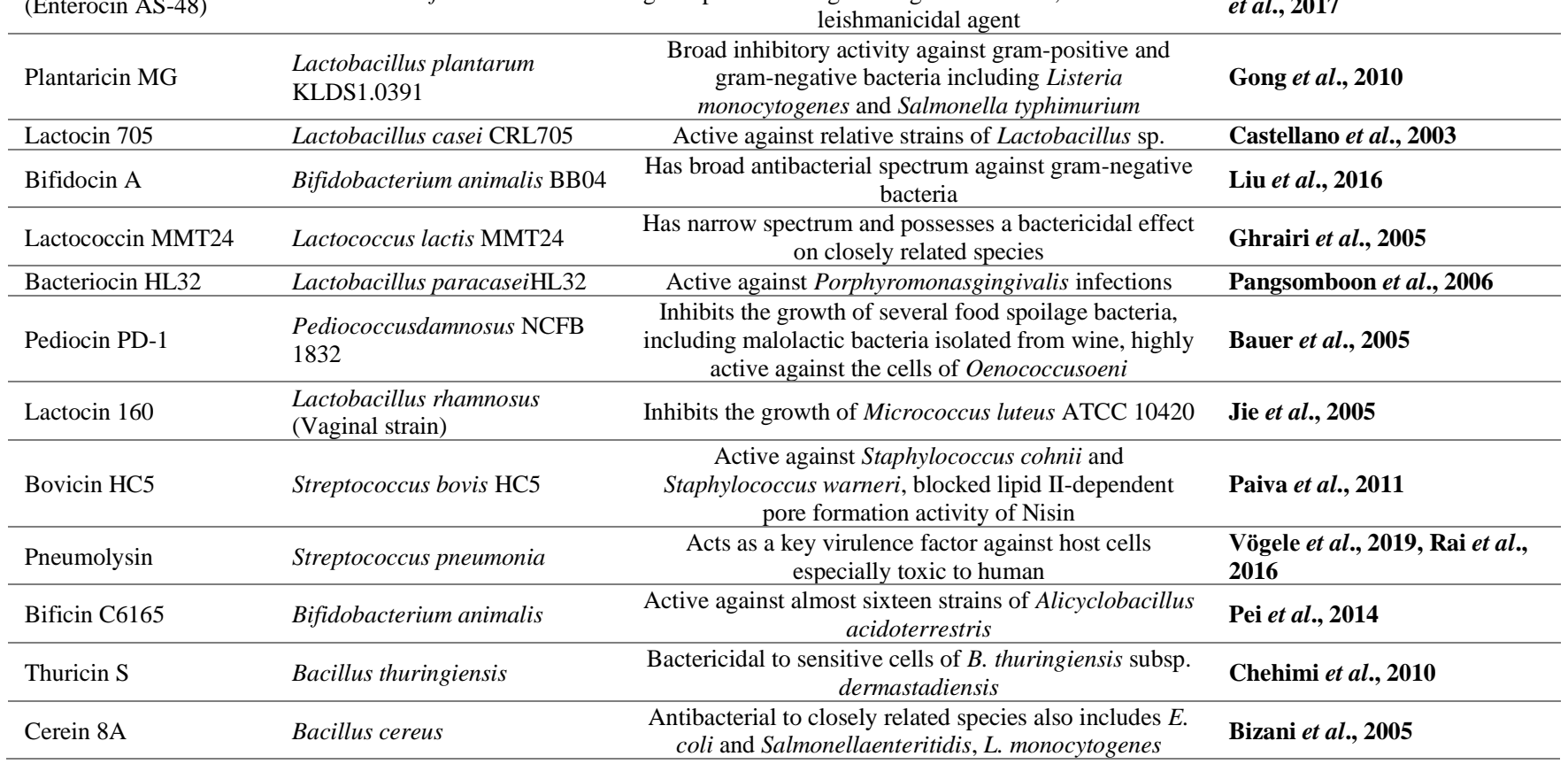

Ref.

Michalek et al., 2013

Wayah and Philip, 2018

Ghequireet al., 2017

Parada et al., 2007, Abeeet al., 2003

Chiumentoetal., 2019

Zamfiret al., 2007, 2009

a bactericidal effect on Lactobacillus strains a

Cause hemolytic phenotype of several E. coli strains

Exerts antibacterial action on related strains and also

has a cytotoxic effect on malignant human cell lines

Forms a huge toroidal pore, antibacterial to the targeted cell even at nanomolar range

Acts on a broad range of gram-positive bacteria including L. lactis, L. monocytogenes, B. subtilis Active against the relative strains forms hydrophilic pores

Fahieet al., 2013

Lagos et al., 2009

Yoneyamaet al., 2009

McAuliffe et al., 1998

Chikinidas et al., 1993

Antibacterial to the relative strains where activity depends on the complementary action of two peptides

Nissen-Meyer et al., 1992

Tahara et al., 1996

Has narrow inhibitory spectrum

Marciset et al., 1997

Exhibit a non-typical antilisterialporation complex

Has broad-spectrum antimicrobial activity against

ram-positive and gram-negative bacteria, also acts as a

Cruz et al., 2013; Abengózar

Gong et al., 2010 monocytogenes and Salmonella typhimurium

Castellano et al., 2003

Ghrairi et al., 2005

Active against Porphyromonasgingivalis infections

Inhibits the growth of several food spoilage bacteria, malolactic bacteria isolated from wine, high

Bauer et al., 2005

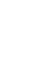

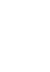


Table 2 List of some bacteriocins that follow the cell wall inhibition mechanism

\begin{tabular}{|c|c|c|c|}
\hline Name of the bacteriocin & Producing microorganism & Inhibition spectrum & Ref. \\
\hline Enterolysin A (pH regulated) & Enterococcus faecalis LMG 2333 & $\begin{array}{l}\text { Inhibits the growth of selected enterococci, } \\
\text { pediococci, lactococci and lactobacilli }\end{array}$ & Nilsen et al., 2003 \\
\hline Helveticin-M & Lactobacillus crispatus & $\begin{array}{c}\text { Disrupts the cell wall of gram-positive bacteria and } \\
\text { disorganized the outer memberane of gram negative } \\
\text { bacteria. Active against } S \text {. aureus, } S \text {. saprophyticus } \\
\text { and Enterobacter cloacae. }\end{array}$ & Sun et al., 2018 \\
\hline Colicin M (29.5kDa) & Escherichia coli & Kills susceptible E. coli cells and other related strains & Barreteau et al., 2012 \\
\hline BacC1 & Enterococcus faecium $\mathrm{C} 1$ & Inhibit the growth of selective food spoilage bacteria & Goh \& Philip, 2015 \\
\hline $\begin{array}{l}\text { PLNC } 8 \alpha \beta \text { (two peptide } \\
\text { bacteriocin) }\end{array}$ & Lactobacillus plantarum NC8 & $\begin{array}{l}\text { Effective against periodontal pathogen } \\
\text { Porphyromonas gingivalis (may form pores causing } \\
\text { intracellular leakage) }\end{array}$ & Khalaf et al., 2016 \\
\hline Mersacidin & Bacillus spp. & Susceptible to gram-positive bacteria & Lajis, 2020 \\
\hline Nisin & Lactococcus lactis & Kills vegetative cells of gram-positive bacteria & Jozala et al., 2015 \\
\hline Lysostaphin & $\begin{array}{l}\text { Staphylococcus simulans bv. } \\
\text { staphylolyticus }\end{array}$ & $\begin{array}{l}\text { Effective against } S . \text { aureus and may other relative } \\
\text { strains }\end{array}$ & Gründling et al., 2006 \\
\hline S.s bacteriocin & Streptococcus sanguinis & $\begin{array}{c}\text { Effective against Candida albicans and Candida } \\
\text { tropicalis }\end{array}$ & Ma et al., 2015 \\
\hline Planosporicin & Planomonospora spp. & $\begin{array}{l}\text { Active against gram positive pathogens of medical } \\
\text { importance, including multi-resistant clinical isolates }\end{array}$ & Castiglione et al., 2007 \\
\hline Acidocin 1B & Lactobacillus acidophilus GP1B & $\begin{array}{l}\text { Active against LAB and other pathogens including } \\
\text { gram negative bacteria }\end{array}$ & Han et al., 2007 \\
\hline Butyricin 7423 & $\begin{array}{l}\text { Clostridium butyricum } \\
\text { NCIB7423 }\end{array}$ & $\begin{array}{l}\text { Have non-lytic action on } C \text {. pasteurianum but } \\
\text { bactericidal to other species of Clostridium }\end{array}$ & Clarke et al., 1976 \\
\hline Halocin H6 & Halobacterial sp. & Inhibit the growth of other halobacteria & Torreblanca et al., 1990 \\
\hline $\begin{array}{l}\text { Pln } 149 \text { (amphipathic } \alpha \text { - } \\
\text { helical antimicrobial peptide) }\end{array}$ & $\begin{array}{l}\text { Lactobacillus plantarum NRIC } \\
149\end{array}$ & $\begin{array}{l}\text { Active against } S \text {. cerevisiae, applicable in food } \\
\text { industries for disrupting cells as non-enzymatic /non- } \\
\text { mechanical process }\end{array}$ & Lopes et al., 2009 \\
\hline Millericin B & $\begin{array}{l}\text { Streptococcus milleri } \\
\text { NMSCC } 061\end{array}$ & $\begin{array}{l}\text { Active against broad spectrum of gram positive } \\
\text { bacteria except } B \text {. subtilis W } 23 \text { and } E \text {. coli ATCC } 486 \\
\text { or against the producer strain itself }\end{array}$ & Beukes et al., 2000 \\
\hline $\begin{array}{l}\text { NAI-107 } \\
\text { (microbisporicin) }\end{array}$ & $\begin{array}{l}\text { Microbispora s. ATCC PTA- } \\
5024\end{array}$ & $\begin{array}{c}\text { Active against multi-drug resistant gram-positive } \\
\text { pathogens including MRSA and VRE and some gram } \\
\text { negative spp. }\end{array}$ & Münch et al., 2014 \\
\hline SK 119 & $\begin{array}{l}\text { L. plantarum subsp. plantarum } \\
\text { SK119 }\end{array}$ & $\begin{array}{l}\text { Listeria active bacteriocin (also forms pores but } \\
\text { researchers insists that cell death associated with } \\
\text { damage of cell membrane) }\end{array}$ & Botthoulath et al., 2018 \\
\hline Mesenterocin 52A & $\begin{array}{l}\text { Leuconostoc mesenteroides } \\
\text { subsp. Mesenteroides FR52 }\end{array}$ & $\begin{array}{l}\text { Inhibit membrane of Listeria ivanovii CIP } 12510 \\
\text { without pore formation and of Listeria innocua CIP } \\
12511 \text { with pore formation }\end{array}$ & Jasniewski et al., 2008 \\
\hline
\end{tabular}

\section{Nuclease activity inhibition/ protein inhibition}

Generally, the nuclease activity involves the breakdown of macromolecules like the disruption of bonds between nucleotides in nucleic acids such as DNA and RNA. Table 3. showed the list of bacteriocins that inhibits protein or nuclease activity of the targeted cell. The bacteriocins which follow this mechanism are also known as nuclease bacteriocins (NBs). Different nuclease bacteriocins are involved in the inhibition of DNA, RNA and protein synthesis together with permease function and show the primary effect on the deployment of energy by the bacterium (Reeves, 1972). They usually have a broad range of size, ranges from 178 to 777 amino acid (Bindiyaet al., 2016). The colicins, plasmid encoded bacteriocin from Escherichia coli also shows nuclease activity. Even the colicin $\mathrm{E} 1$ and $\mathrm{K}$ inhibits all macromolecule synthesis without the arrest of respiration while others may act by cleaving the precise site of particular nucleic acid (Cascaleset al., 2007). They contain an $\mathrm{N}$-terminal translocation domain, a central receptor binding domain and a $\mathrm{C}$-terminal cytotoxic domain that binds a cognate immunity protein however the location of the translocation and receptor-binding domains in pyocins (bacteriocins from Pseudomonas aeruginosa) appears to be reverse (Atanaskovic et al., 2019). Translocations of nuclease colicins across the outer and inner membrane must be necessary to achieve their target in the cytoplasm (Cascales et al., 2007; de Zamaroczy et al., 2011). During translocation, the immunity proteins of nuclease colicins may be dissociated at the cell surface in a pmf-dependent step (Sharp et al., 2017). The nuclease bacteriocin delivered to the cytoplasm of a targeted cell which involves the DNA chromosomal cleavage randomly led to the cell death. Many nuclease colicins like colicin E2, E7, E8 and E9 found to exhibit their antimicrobial activity by the action of DNase which involves the non-specific cleavage of genomic DNA (Schaller et al., 1976; Chaket al., 1991; Cooper et al., 1984).HNH/ $\beta \beta \alpha-M e$ motif acts as the catalytic centre of many colicins and pyocins DNases by hydrolyzing the phosphodiester bond through chelation with a single divalent metal ion (Klein et al., 2016) Walker et al., (2007) showed that the toxic action of nuclease colicins depends upon functional FtsH, an inner membrane $\mathrm{AAA}^{+}$ATPase and protease that dislocates misfolded membrane proteins to the cytoplasm of a targeted cell as to cause cell death. LepB which is an important inner membrane enzyme of $E$. coliand a key membrane component of cellular secretion machinery offered a chaperonlike function for the penetration of several nuclease bacteriocins into a target cell in addition to this it was also reported as the necessary component of machinery hijacked by the tRNase colicin D for its import (Mora et al., 2015). Colicin like E3, E4, E6 exhibit RNase activity, out of which Colicin E3 is most widely studied, which is known to cleaves the 3' region of 16-S rRNA between A1493 and G1494 (E. coli numbering) in the decoding A-site and decreases the acceptance of cognate aminoacyl-tRNAs (aa-tRNAs) and thus slow down the protein synthesis and finally cause the death of the targeted cell (Ogawa et al., 2016).

\section{ATP SYNTHESIS INHIBITION}

Many bacteriocins also show their antimicrobial activity by inhibiting the ATP synthesis or by the release of ATP out of the cell. The bacteriocin that showed the ATP inhibition accompanied by other mechanisms is shown in Table 4 . The ATP synthesis inhibition accompanied by either cell wall synthesis inhibition or by pore formation which allows the secretion or reduction of ATP along with other ionic molecules as stated by many researchers. There are many examples of bacteriocins that involved in ATP synthesis inhibition like mesentericin Y105 produced by Leuconostoc mesenteroides strain which is a pore-forming bacteriocin, had been found to show the effects on cell organelle, where it uncouples the mitochondria by increasing state 4 respiration and decreasing state 3 respiration. It also inhibits the ATP synthase and adenine nucleotide translocase of the organelle (Maftah et al., 1993). Similarly, microcin J25 also showed inhibition of ATP along with concomitant enhancement of ATP degradation. It was also observed for altering the membrane permeability and inhibiting the enzymatic activity of cytochrome C reductase (complex III) of the respiratory chain (Chirou et al., 2004). The increased ATPase activity found to be responsible for acid sensitivity of nisinresistant Listeria monocytogenes which cause cell death on the addition of an acid like hydrochloric acid or lactic acid (McEntire $\boldsymbol{e t}$ al., 2004). Sometimes, as a consequence of a shift in the ATP equilibrium, the ATP is hydrolysed into ADP and AMP due to the efflux of phosphate through the channels (Guihard $\boldsymbol{e t}$ al., 
1993). Here, we represent the list of some bacteriocins that involves in the inhibition of ATP synthesis either as a primary or as a secondary action of these antimicrobial proteins

\begin{tabular}{|c|c|c|c|c|}
\hline $\begin{array}{l}\text { Name of the } \\
\text { bacteriocin }\end{array}$ & Producing microorganisn & Mode of action & Inhibition spectrum & Ref. \\
\hline $\begin{array}{l}\text { Colicin (E3, E4, E5, } \\
\text { E6 and D) }\end{array}$ & E. coli strains & $\begin{array}{l}\text { Found to inhibit protein } \\
\text { biosynthesis by cleaving } 16 \mathrm{~s} \\
\text { rRNA or tRNAs }\end{array}$ & $\begin{array}{c}\text { Active against some } \\
\text { other strains of } E \text {. coli } \\
\text { and other related bacteria }\end{array}$ & Kaur et al., 2015 \\
\hline Smegmatocin & $\begin{array}{l}\text { Mycobacterium } \\
\text { smegmatis }\end{array}$ & $\begin{array}{l}\text { Inhibits the protein and DNA } \\
\text { synthesis }\end{array}$ & $\begin{array}{l}\text { Sensitive to Mks-A TU-7 } \\
\text { cells }\end{array}$ & Kaur et al., 2015 \\
\hline Colicin E2 & E. coli $\mathrm{K} 12$ & $\begin{array}{c}\text { Cause specific inhibition of DNA } \\
\text { synthesis and induce DNA } \\
\text { damage }\end{array}$ & $\begin{array}{c}\text { Active against } \\
\text { uropathogenic } E \text {. coli } \\
\text { and other related strains }\end{array}$ & $\begin{array}{l}\text { Konisky, 1982; } \\
\text { Pugsley } \text { et al., 1985; } \\
\text { Trivedi } \text { et al., } 2014\end{array}$ \\
\hline Colicin L & Serratia marcescens & $\begin{array}{l}\text { Inhibits the synthesis of proteins, } \\
\text { DNA, RNA }\end{array}$ & $\begin{array}{l}\text { Active against certain } \\
\text { strains of } E \text {. coli }\end{array}$ & Konisky, 1982 \\
\hline Butyricin 7423 & $\begin{array}{l}\text { Clostridium butyricum } \\
7423\end{array}$ & $\begin{array}{l}\text { Inhibit the synthesis of proteins, } \\
\text { DNA, RNA, also lowers the ATP } \\
\text { levels }\end{array}$ & $\begin{array}{l}\text { Active against } \\
\text { Clostridium } \\
\text { pasteurianum }\end{array}$ & Konisky, 1982 \\
\hline Pyocin AP41 & $\begin{array}{l}\text { Pseudomonas } \\
\text { aeruginosa } \mathrm{PAF} 41\end{array}$ & In vivo, inhibits DNA synthesis & $\begin{array}{l}\text { Sensitive to } P \text {. } \\
\text { aeruginosa strains }\end{array}$ & Konisky, 1982 \\
\hline Carocin S2 & $\begin{array}{l}\text { Pectobacterium } \\
\text { carotovorum }\end{array}$ & $\begin{array}{c}\text { Cause exhausting supply of RNA } \\
\text { which led to inactivation of } \\
\text { protein synthesis }\end{array}$ & $\begin{array}{l}\text { Inhibits the growth of } \\
\text { closely related species }\end{array}$ & Chan et al., 2011 \\
\hline $\begin{array}{l}\text { Bacteriocin } \\
\text { (Unclassified) }\end{array}$ & $\begin{array}{l}\text { Bacteroides fragilis } \\
\text { strain }\end{array}$ & $\begin{array}{c}\text { Inhibits RNA synthesis which led } \\
\text { to the inhibition of protein } \\
\text { synthesis but has no effect on } \\
\text { DNA }\end{array}$ & $\begin{array}{l}\text { Active only against } \\
\text { closely related strains }\end{array}$ & Mossie etal., 1979 \\
\hline Staphylococcin 1580 & $\begin{array}{l}\text { Staphylococcus } \\
\text { epidermidis }\end{array}$ & $\begin{array}{c}\text { Inhibit the synthesis of proteins, } \\
\text { DNA, RNA but also have effects } \\
\text { on membrane }\end{array}$ & $\begin{array}{c}\text { bactericidal to many } \\
\text { gram positive bacteria } \\
\text { and stable staphylococcal } \\
\text { L-forms }\end{array}$ & $\begin{array}{l}\text { Jetten and Vogels, } \\
1972\end{array}$ \\
\hline $\begin{array}{l}\text { Bacteriocin } \\
\text { (unclassified) }\end{array}$ & Bacteroides fragilis & $\begin{array}{c}\text { Inhibit ribonucleic acid } \\
\text { polymerase }\end{array}$ & $\begin{array}{c}\text { narrow spectrum of } \\
\text { activity }\end{array}$ & Mossie et al., 1981 \\
\hline Enterocin E1A \& E1B & $\begin{array}{l}\text { Streptococcus faecium } \\
\text { E1 }\end{array}$ & $\begin{array}{l}\text { Without degrading DNA or RNA } \\
\text { it inhibits the synthesis of } \\
\text { proteins, DNA and RNA }\end{array}$ & $\begin{array}{l}\text { Active only against } \\
\text { certain strains of } \\
\text { enterococci, } S . \\
\text { salivarius } \& L . \\
\text { monocytogens }\end{array}$ & $\begin{array}{l}\text { Kramer \& Brandis, } \\
1975\end{array}$ \\
\hline Megacin C & Bacillus megaterium & $\begin{array}{l}\text { Inhibits DNA synthesis while } \\
\text { protein and RNA are little effected }\end{array}$ & $\begin{array}{c}\text { Specific for other strains } \\
\text { of species as well as } \\
\text { some closely related } \\
\text { strains }\end{array}$ & Holland, 1965 \\
\hline Lactostrepcin 5 & $\begin{array}{l}\text { Lactococcus lactis } \\
\text { subsp. cremoris } 202\end{array}$ & $\begin{array}{l}\text { Inhibits the synthesis of proteins, } \\
\text { DNA and RNA, also cause ion } \\
\text { leakage and interfere with uridine } \\
\text { transport }\end{array}$ & $\begin{array}{l}\text { Antimicrobial against } \\
\text { lactococci }\end{array}$ & Nettles et al., 1993 \\
\hline Agrocin 84 & $\begin{array}{l}\text { Agrobacterium } \\
\text { radiobacter }\end{array}$ & $\begin{array}{l}\text { Inhibits DNA synthesis without } \\
\text { degrading it }\end{array}$ & $\begin{array}{c}\text { Antimicrobial against } \\
\text { oncogenic strains of } A . \\
\text { Tumefaciens }\end{array}$ & Das et al., 1978 \\
\hline Marcescin A & Serratia marcesens HY & $\begin{array}{c}\text { Inhibit DNA, RNA, protein } \\
\text { synthesis, also degrades DNA \& } \\
\text { RNA }\end{array}$ & $\begin{array}{l}\text { Active against strains of } \\
S . \text { marcescens \& E. coli }\end{array}$ & $\begin{array}{l}\text { Eichenlaub et al., } \\
1974\end{array}$ \\
\hline Mercescin B & Serratia marcesens HY & $\begin{array}{l}\text { Only inhibits DNA, RNA, protein } \\
\text { synthesis }\end{array}$ & $\begin{array}{l}\text { Active only against } E . \\
\text { coli } \text { strains }\end{array}$ & $\begin{array}{l}\text { Eichenlaub et al., } \\
1974\end{array}$ \\
\hline Lactocin 27 & $\begin{array}{l}\text { Lactobacillus helveticus } \\
\text { strain LP27 }\end{array}$ & $\begin{array}{l}\text { Inhibits primarily protein } \\
\text { synthesis }\end{array}$ & $\begin{array}{c}\text { Bacteriostatic to } L . \\
\text { helveticus strain LS18 }\end{array}$ & Upreti et al., 1975 \\
\hline Streptocin A & $\begin{array}{l}\text { Group A Streptococcus } \\
\text { strain FF-22 }\end{array}$ & $\begin{array}{l}\text { Inhibit DNA, RNA, protein } \\
\text { synthesis, also interfere with the } \\
\text { uptake and incorporation of } \\
\text { glucose }\end{array}$ & $\begin{array}{c}\text { Has bactericidal effect on } \\
\text { Group A Streptococcus } \\
\text { species }\end{array}$ & Tagg et al., 1973 \\
\hline Bacteriocin DF13 & $\begin{array}{l}\text { Enterobacter cloacae } \\
\text { DF13 }\end{array}$ & $\begin{array}{l}\text { Inhibits primarily protein } \\
\text { synthesis had no effect on DNA \& } \\
\text { RNA synthesis }\end{array}$ & $\begin{array}{l}\text { Has killing action on } \\
\text { Klebsiella edwardsii }\end{array}$ & Graaf et al., 1969 \\
\hline Staphylococcin 462 & $\begin{array}{l}\text { Staphylococcus aureus } \\
\text { strain } 462\end{array}$ & $\begin{array}{l}\text { Stop protein synthesis, also } \\
\text { inhibits the DNA \& RNA } \\
\text { synthesis but does not stop it }\end{array}$ & $\begin{array}{c}\text { Active against S.aureus } \\
140\end{array}$ & Hale et al., 1975 \\
\hline Bacteriocin Bc-48 & $\begin{array}{l}\text { Enterococcus faecalis } \\
\text { ssp. Liquefaciens } S-48 \\
\text { and its mutant } B-48- \\
28\left(A S-48^{-}\right)\end{array}$ & $\begin{array}{l}\text { Inhibits protein synthesis but does } \\
\text { not affect amino acid uptake }\end{array}$ & $\begin{array}{l}\text { Inhibition spectrum } \\
\text { restricted to strains of } E \text {. } \\
\text { faecalis }\end{array}$ & $\begin{array}{l}\text { Lopez-Lara et al., } \\
1991\end{array}$ \\
\hline Clostocin $\mathrm{O}$ & $\begin{array}{l}\text { Clostridium } \\
\text { saccharoperbutylacet- } \\
\text { onicum }\end{array}$ & $\begin{array}{l}\text { Synthesis of DNA, mRNA and } \\
\text { mononucleotides, moderately } \\
\text { effects the lipid, mRNA and } \\
\text { protein synthesis }\end{array}$ & $\begin{array}{l}\text { Active only against } \\
\text { closely related strains }\end{array}$ & Kato et al., 1977 \\
\hline Pneumolysin & $\begin{array}{l}\text { Streptococcus } \\
\text { pneumoniae }\end{array}$ & $\begin{array}{l}\text { Induce DNA damage and cell } \\
\text { cycle arrest }\end{array}$ & $\begin{array}{c}\text { Effective against } S . \\
\text { pneumoniae infections }\end{array}$ & Rai et al., 2016 \\
\hline
\end{tabular}




\begin{tabular}{llcc} 
Sublancin & Bacillus subtilis 168 & $\begin{array}{c}\text { Effects DNA replication, } \\
\text { transcription and RNA translation }\end{array}$ & $\begin{array}{c}\text { Effective against gram- } \\
\text { positive bacteria } \\
\text { including MRSA }\end{array}$ \\
\hline
\end{tabular}

Table 4 List of bacteriocin that shows ATP inhibition accompanied by other mechanisms

\begin{tabular}{|c|c|c|c|c|}
\hline $\begin{array}{l}\text { Name of } \\
\text { the } \\
\text { bacteriocin }\end{array}$ & $\begin{array}{l}\text { Producing } \\
\text { microorganism }\end{array}$ & Primary mechanism & Effect on ATP & Ref. \\
\hline Pyocin R1 & $\begin{array}{l}\text { Pseudomonas } \\
\text { aeruginosa }\end{array}$ & $\begin{array}{l}\text { Memberane } \\
\text { depolarization }\end{array}$ & $\begin{array}{l}\text { Cause decrease in intracellular ATP level without } \\
\text { affecting the respiration of sensitive cells }\end{array}$ & Uratani et al., 1984 \\
\hline $\begin{array}{l}\text { Linenscin } \\
\text { OC2 }\end{array}$ & $\begin{array}{l}\text { Brevibacterium } \\
\text { linensOC2 }\end{array}$ & $\begin{array}{c}\text { Acts on cytoplasmic } \\
\text { membrane } \\
\text { (Membrane } \\
\text { depolarization), active } \\
\text { against Listeria } \\
\text { innocua }\end{array}$ & $\begin{array}{l}\text { Cause hydrolysis of internal ATP along with efflux of } \\
\mathrm{Pi} \text { and cause transient increase in oxygen consumption }\end{array}$ & Boucabeille et al., 1998 \\
\hline $\begin{array}{l}\text { Enterocin } \\
\text { LD3 }\end{array}$ & $\begin{array}{l}\text { Enterococcus hirae } \\
\text { LD3 }\end{array}$ & $\begin{array}{l}\text { Cause dissipation of cell } \\
\text { membrane (inhibits } \\
\text { gram positive and } \\
\text { gram negative bacteria } \\
\text { including human } \\
\text { pathogens) }\end{array}$ & Loss of internal ATP & Gupta et al., 2016 \\
\hline $\begin{array}{l}\text { Pediocin } \\
\text { PA-1 }\end{array}$ & $\begin{array}{l}\text { Pediococcus } \\
\text { acidilactici PAC } 1.0\end{array}$ & Pore formation & $\begin{array}{l}\text { ATP depletion occurs in concentration and time- } \\
\text { dependent manner, also induce irreversible } \mathrm{K}^{+} \text {and Pi } \\
\text { efflux }\end{array}$ & $\begin{array}{l}\text { Chen } \text { et al., 1995; } \\
\text { Chikinidas } \text { et al.,1993 }\end{array}$ \\
\hline Nisin A & $\begin{array}{l}\text { Lactococcus lactis } \\
\text { strains }\end{array}$ & 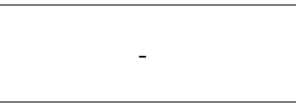 & $\begin{array}{c}\text { Reduced the ATP and cause the leakage of intracellular } \\
\text { ATP out of the targeted cell i.e. Mycobacterium } \\
\text { smegmatis }\end{array}$ & Montville et al., 1999 \\
\hline $\begin{array}{l}\text { Pentocin } \\
\text { 31-1 }\end{array}$ & $\begin{array}{l}\text { Lactobacillus } \\
\text { pentosus }\end{array}$ & $\begin{array}{c}\text { Cause cell membrane } \\
\text { permeabilization }\end{array}$ & Efflux of ATP along with $\mathrm{K}^{+}$and Pi & Zhou et al., 2008 \\
\hline Viridin B & $\begin{array}{l}\text { Streptococcus mitis } \\
\text { (mitior) }\end{array}$ & $\begin{array}{l}\text { Block macromolecule } \\
\text { synthesis without } \\
\text { causing any } \\
\text { degradation }\end{array}$ & $\begin{array}{l}\text { ATP production of targeted cell was slightly enhanced } \\
\text { within } 1 \mathrm{~h} \text { of exposure to bacteriocin }\end{array}$ & Law et al., 1978 \\
\hline Lactacin F & $\begin{array}{l}\text { Lactobacillus } \\
\text { johnsonii }\end{array}$ & $\begin{array}{l}\text { Form poration complex } \\
\text { in cytoplasmic } \\
\text { membrane }\end{array}$ & $\begin{array}{c}\text { Cause hydrolysis of internal ATP along with loss of } \\
\text { cellular } \mathrm{K}^{+}\end{array}$ & Abee et al., 1994 \\
\hline $\begin{array}{l}\text { Bacteriocin } \\
\text { CHQS }\end{array}$ & $\begin{array}{l}\text { Enterococcus faecalis } \\
T G 2\end{array}$ & $\begin{array}{l}\text { Changes the cell } \\
\text { membrane } \\
\text { permeability, integrity } \\
\text { and proton motive } \\
\text { force }\end{array}$ & $\begin{array}{c}\text { Cause massive release of ATP and UV absorbing } \\
\text { materials }\end{array}$ & Cao et al., 2019 \\
\hline $\begin{array}{l}\text { Bacteriocin } \\
2 \mathbf{a}\end{array}$ & $\begin{array}{l}\text { Lactobacillus sake } \\
\text { strain }\end{array}$ & Pore formation & $\begin{array}{c}\text { Reduce the intracellular ATP with no detectable } \\
\text { increase in extracellular ATP }\end{array}$ & Rosa et al., 2002 \\
\hline $\begin{array}{l}\text { Piscicocin } \\
\text { CS526 }\end{array}$ & $\begin{array}{l}\text { Carnobacterium } \\
\text { piscicola } \text { CS526 }\end{array}$ & Pore formation & $\begin{array}{l}\text { ATP level rapidly reduced without leakage of ATP from } \\
\text { the cells, indicating ATP depletion }\end{array}$ & Suzuki et al., 2005 \\
\hline
\end{tabular}

\section{CONCLUSION}

As described above, we can recapitulate that how these bacteriocins are inhibiting the growth of bacteria replacing the hazardous chemical preservatives in agro-food industries and become prominence for society as they involve in the killing of pathogens by following mechanisms. Due to their diversity in various aspects like mode of action, uses and their habitat they may provide new and more advanced pathways for researchers in the area of medical, pharma, agriculture and food biotechnology for the sake of humanity. To overcome, antibiotic-resistant related issue in the medical sector this can warrant an alternative and provide the researchers to remove insurmountable difficulties.

CONFLICTS OF INTEREST: No potential conflict of interest was reported by the authors.

\section{REFERENCES}

Abee, T., \& Delves-Broughton, J. (2003). Bacteriocins-Nisin. In: Russell NJ, Gould GW (eds). Food Preservatives. Springer, Boston, MA https://doi.org/10.1007/978-0-387-30042-9_8

Abee, T., Klaenhammer, T. R., \& Letellier, L. (1994). Kinetic studies of the action of lactacin F, a bacteriocin produced by Lactobacillus johnsonii that forms poration complexes in the cytoplasmic membrane. Applied and Environmental Microbiology, 60(3), 1006-1013.

Abengózar, M. Á., Cebrián, R., Saugar, J. M., Gárate, T., Valdivia, E., MartínezBueno, M., ... \& Rivas, L. (2017). Enterocin AS-48 as evidence for the use of bacteriocins as new leishmanicidal agents. Antimicrobial agents and chemotherapy, 61(4), e02288-16. https://doi.org/10.1128/AAC.02288-16 Adams, M. R., \& Moss, M. O. (2008). Food microbiology. Royal society of chemistry.
AlKhatib, Z., Lagedroste, M., Fey, I., Kleinschrodt, D., Abts, A., \& Smits, S. H. (2014). Lantibiotic immunity: inhibition of nisin mediated pore formation by NisI. PloS one, 9(7), e102246.

Alouf, J. E. (2003). Molecular features of the cytolytic pore-forming bacterial protein toxins. Folia microbiologica, 48(1), 5.

Anderluh, G., \& Lakey, J. H. (2008). Disparate proteins use similar architectures to damage membranes. Trends in biochemical sciences, 33(10), 482-490.

Atanaskovic, I., \& Kleanthous, C. (2019). Tools and approaches for dissecting protein bacteriocin import in gram-negative bacteria. Frontiers in microbiology, 10, 646. https://doi.org/10.3389/fmicb.2019.00646

Baindara, P., Korpole, S., \& Grover, V. (2018). Bacteriocins: perspective for the development of novel anticancer drugs. Applied microbiology and biotechnology, 102(24), 10393-10408.

Barreteau, H., El Ghachi, M., Barnéoud-Arnoulet, A., Sacco, E., Touzé, T., Duché, D., ... \& Mengin-Lecreulx, D. (2012). Characterization of colicin M and its orthologs targeting bacterial cell wall peptidoglycan biosynthesis. Microbial Drug Resistance, 18(3), 222-229. https://doi.org/10.1089/mdr.2011.0230

Bauer, R., Chikindas, M. L., \& Dicks, L. M. T. (2005). Purification, partial amino acid sequence and mode of action of pediocin PD-1, a bacteriocin produced by Pediococcus damnosus NCFB 1832. International journal of food microbiology, 101(1), 17-27.

Beukes, M., Bierbaum, G., Sahl, H. G., \& Hastings, J. W. (2000). Purification and partial characterization of a murein hydrolase, millericin B, produced by Streptococcus milleri NMSCC 061. Applied and Environmental Microbiology, 66(1), 23-28.

Bindiya, E. S., \& Bhat, S. G. (2016). Marine bacteriocins: A review. Journal of Bacteriology \& Mycology: Open Access, 2(5), 00040.. DOI: 10.15406/jbmoa.2016.02.00040 
Bizani, D., Motta, A. S., Morrissy, J. A., Terra, R., Souto, A. A., \& Brandelli, A. (2005). Antibacterial activity of cerein 8 A, a bacteriocin-like peptide produced by Bacillus cereus. International Microbiology, 8(2), 125-131

Botthoulath, V., Upaichit, A., \& Thumarat, U. (2018). Characterization of Listeria-active bacteriocin produced by a new strain Lactobacillus plantarum subsp. plantarum SKI19 isolated from" sai krok e-san mu". International Food Research Journal, 25(6), 2362-2371.

Boucabeille, C., Letellier, L., Simonet, J. M., \& Henckes, G. (1998). Mode of action of linenscin OC2 against Listeria innocua. Applied and environmental microbiology, 64(9), 3416-3421.

Breukink, E., van Heusden, H. E., Vollmerhaus, P. J., Swiezewska, E., Brunner, L., Walker, S., ... \& de Kruijff, B. (2003). Lipid II is an intrinsic component of the pore induced by nisin in bacterial membranes. Journal of Biological Chemistry, 278(22), 19898-19903.

Cao, S., Du, R., Zhao, F., Xiao, H., Han, Y., \& Zhou, Z. (2019). The mode of action of bacteriocin CHQS, a high antibacterial activity bacteriocin produced by Enterococcus faecalis TG2. Food Control, 96, 470-478.

Cascales, E., Buchanan, S. K., Duché, D., Kleanthous, C., Lloubes, R., Postle, K. ... \& Cavard, D. (2007). Colicin biology. Microbiology and molecular biology reviews, $71(1), 158-229$

Castellano, P., Raya, R., \& Vignolo, G. (2003). Mode of action of lactocin 705, a two-component bacteriocin from Lactobacillus casei CRL705. International journal of food microbiology, 85(1-2), 35-43.

Castiglione, F., Cavaletti, L., Losi, D., Lazzarini, A., Carrano, L., Feroggio, M., ... \& Selva, E. (2007). A novel lantibiotic acting on bacterial cell wall synthesis produced by the uncommon actinomycete Planomonospora sp. Biochemistry, 46(20), 5884-5895.

Chak, K. F., Kuo, W. S., \& James, R. (1991). Cloning and characterization of the ColE7 plasmid. Microbiology, 137(1), 91-100.

Chan, Y. C., Wu, J. L., Wu, H. P., Tzeng, K. C., \& Chuang, D. Y. (2011). Cloning, purification, and functional characterization of Carocin S2, a ribonuclease bacteriocin produced by Pectobacterium carotovorum. BMC microbiology, 11(1), 1-12. https://doi.org/10.1186/1471-2180-11-99

Chao, L., \& Levin, B. R. (1981). Structured habitats and the evolution of anticompetitor toxins in bacteria. Proceedings of the National Academy of Sciences, 78(10), 6324-6328.

Chehimi, S., Pons, A. M., Sable, S., Hajlaoui, M. R., \& Limam, F. (2010). Mode of action of thuricin $\mathrm{S}$, a new class IId bacteriocin from Bacillus thuringiensis. Canadian journal of microbiology, 56(2), 162-167.

Chen, Y., \& Montville, T. J. (1995). Efflux of ions and ATP depletion induced by pediocin PA-1 are concomitant with cell death in Listeria monocytogenes Scott A. Journal of applied bacteriology, 79(6), 684-690.

Chikindas, M. L., García-Garcerá, M. J., Driessen, A. J., Ledeboer, A. M. Nissen-Meyer, J., Nes, I. F., ... \& Venema, G. (1993). Pediocin PA-1, a bacteriocin from Pediococcus acidilactici PAC1. 0, forms hydrophilic pores in the cytoplasmic membrane of target cells. Applied and Environmental Microbiology, 59(11), 3577 3584 .

Chirou, M. V. N., Minahk, C. J., \& Morero, R. D. (2004). Antimitochondrial activity displayed by the antimicrobial peptide microcin $\mathrm{J} 25$. Biochemical and biophysical research communications, 317(3), 882-886.

Chiumento, S., Roblin, C., Kieffer-Jaquinod, S., Tachon, S., Leprètre, C., Basset, C., ... \& Duarte, V. (2019). Ruminococcin C, a promising antibiotic produced by a human gut symbiont. Science advances, 5(9), eaaw9969.

Christ, K., Wiedemann, I., Bakowsky, U., Sahl, H. G., \& Bendas, G. (2007). The role of lipid II in membrane binding of and pore formation by nisin analyzed by two combined biosensor techniques. Biochimica et Biophysica Acta (BBA) Biomembranes, 1768(3), 694-704.

Clarke, D. J., \& Morris, J. G. (1976). Butyricin 7423: a bacteriocin produced by Clostridium butyricum NCIB7423. Microbiology, 95(1), 67-77.

Cooper, P. C., \& James, R. (1984). Two new E colicins, E8 and E9, produced by a strain of Escherichia coli. Microbiology, 130(1), 209-215.

Cosentino, K., Ros, U., \& García-Sáez, A. J. (2016). Assembling the puzzle: oligomerization of $\alpha$-pore forming proteins in membranes. Biochimica Et Biophysica Acta (BBA)-Biomembranes, 1858(3), 457-466.

Cotter, P. D., Ross, R. P., \& Hill, C. (2013). Bacteriocins - a viable alternative to antibiotics?. Nature Reviews Microbiology, 11(2), 95-105.

Cruz, V. L., Ramos, J., Melo, M. N., \& Martinez-Salazar, J. (2013). Bacteriocin AS-48 binding to model membranes and pore formation as revealed by coarsegrained simulations. Biochimica et Biophysica Acta (BBA)Biomembranes, 1828(11), 2524-2531.

da Costa, R. J., Voloski, F. L., Mondadori, R. G., Duval, E. H., \& Fiorentini, Â. M. (2019). Preservation of meat products with bacteriocins produced by lactic acid bacteria isolated from meat. Journal of Food Quality, 2019. https://doi.org/10.1155/2019/4726510

Dal Peraro, M., \& Van Der Goot, F. G. (2016). Pore-forming toxins: ancient, but never really out of fashion. Nature reviews microbiology, 14(2), 77-92.

Das, P. K., Basu, M., \& Chatterjee, G. C. (1978). Studies on the mode of action of agrocin 84. The Journal of antibiotics, 31(5), 490-492.
Daw, M. A., \& Falkiner, F. R. (1996). Bacteriocins: nature, function and structure. Micron, 27(6), 467-479.

De Graaf, F. K., Speckman, E. A. S., \& Stouthamer, A. H. (1969). Mode of action of a bacteriocin produced by Enterobacter cloacae DF Antonie van Leeuwenhoek, 35(1), 287-306.

de Zamaroczy, M., \& Chauleau, M. (2011). Colicin killing: foiled cell defense and hijacked cell functions. In Prokaryotic Antimicrobial Peptides (pp. 255-287). Springer, New York, NY.

Eichenlaub, R., \& Winkler, U. (1974). Purification and mode of action of two bacteriocins produced by Serratia marcesens HY. Microbiology, 83(1), 83-94.

Fahie, M., Romano, F. B., Chisholm, C., Heuck, A. P., Zbinden, M., \& Chen, M. (2013). A non-classical assembly pathway of Escherichia coli pore-forming toxin cytolysin A. Journal of Biological Chemistry, 288(43), 31042-31051.

Ghequire, M. G., Kemland, L., Anoz-Carbonell, E., Buchanan, S. K., \& De Mot R. (2017). A natural chimeric Pseudomonas bacteriocin with novel pore-forming activity parasitizes the ferrichrome transporter. MBio, 8(1), e01961-16.

Ghrairi, T., Frere, J., Berjeaud, J. M., \& Manai, M. (2005). Lactococcin MMT24, a novel two-peptide bacteriocin produced by Lactococcus lactis isolated from rigouta cheese. International journal of food microbiology, 105(3), 389-398.

Gillor, O., Etzion, A., \& Riley, M. A. (2008). The dual role of bacteriocins as antiand probiotics. Applied microbiology and biotechnology, 81(4), 591-606 https://doi.org/10.1007/s00253-008-1726-5

Goh, H. F., \& Philip, K. (2015). Isolation and mode of action of bacteriocin BacC1 produced by nonpathogenic Enterococcus faecium $\mathrm{C} 1$. Journal of dairy science, 98(8), 5080-5090. http://dx.doi.org/10.3168.jds.2014-9240

Gong, H. S., Meng, X. C., \& Wang, H. (2010). Mode of action of plantaricin MG, a bacteriocin active against Salmonella typhimurium. Journal of basic microbiology, 50(S1), S37-S45.

Gonzalez, M. R., Bischofberger, M., Pernot, L., Van Der Goot, F. G., \& Freche, B. (2008). Bacterial pore-forming toxins: the (w) hole story. Cellular and Molecular Life Sciences, 65(3), 493-507.

Gratia, A. (1925). Sur un remarquable exemple d'antagonisme entre deux souches de coilbacille. CR Seances Soc. Biol. Fil., 93, 1040-1041.

Gründling, A., \& Schneewind, O. (2006). Cross-linked peptidoglycan mediates lysostaphin binding to the cell wall envelope of Staphylococcus aureus. Journal of bacteriology, 188(7), 2463-2472.

Guihard, G., Bénédetti, H., Besnard, M., \& Letellier, L. (1993). Phosphate efflux through the channels formed by colicins and phage T5 in Escherichia coli cells is responsible for the fall in cytoplasmic ATP. Journal of Biological Chemistry, 268(24), 17775-17780.

Gupta, A., Tiwari, S. K., Netrebov, V., \& Chikindas, M. L. (2016). Biochemical properties and mechanism of action of enterocin LD3 purified from Enterococcus hirae LD3. Probiotics and antimicrobial proteins, 8(3), 161-169.

Hale, E. M., \& Hinsdili, R. D. (1975). Biological activity of staphylococcin 462 bacteriocin from Staphylococcus aureus. Antimicrobial Agents and Chemotherapy, 7(1), 74-81.

Han, K. S., Kim, Y. H., Kim, S. H., \& Oh, S. J. (2007). Characterization and purification of acidocin 1B, a bacteriocin produced by Lactobacillus acidophilus GP1B. Journal of microbiology and biotechnology, 17(5), 774-783.

Hasper, H. E., de Kruijff, B., \& Breukink, E. (2004). Assembly and stability of nisin- lipid II pores. Biochemistry, 43(36), 11567-11575

Hassan, M., Kjos, M., Nes, I. F., Diep, D. B., \& Lotfipour, F. (2012). Natural antimicrobial peptides from bacteria: characteristics and potential applications to fight against antibiotic resistance. Journal of applied microbiology, 113(4), 723 736. https://doi.org/10.1111/j.1365-2672.2012.05338.x

Holland, I. B. (1965). A bacteriocin specifically affecting DNA synthesis in Bacillus megaterium. Journal of molecular biology, 12(2), 429-438. https://doi.org/10.1016/S0022-2836(65)80265-0

Indumathi, K. P., Kaushik, R., Arora, S., \& Wadhwa, B. K. (2015). Evaluation of iron fortified Gouda cheese for sensory and physicochemical attributes. Journal of Food Science and Technology, 52(1), 493-499.

Jabeen N, Gul H, Subhan SA, Hussain M, Ajaz M, Rasool SA. (2009). Biophysicochemical characterization of bacteriocin(s) from indigenously isolated Agrobacterium radiobacter NA6. Pakistan Journal of Botany. 41(6): 3227-3237. Jack, R. W., Tagg, J. R., \& Ray, B. (1995). Bacteriocins of gram-positive bacteria. Microbiological reviews, 59(2), 171-200.

Jacob, F., Lwoff, A., Siminovitch, A., \& Wollman, E. (1953, January). Définition de quelques termes relatifs à la lysogénie. In ANNALES DE L INSTITUT PASTEUR (Vol. 84, No. 1, pp. 222-224). 120 BLVD SAINT-GERMAIN, 75280 PARIS 06, FRANCE: MASSON EDITEUR.

Jasniewski, J., Cailliez-Grimal, C., Younsi, M., Millière, J. B., \& Revol-Junelles, A. M. (2008). Fluorescence anisotropy analysis of the mechanism of action of mesenterocin 52A: speculations on antimicrobial mechanism. Applied microbiology and biotechnology, 81(2), 339-347.

Jetten, A. M., \& Vogels, G. D. (1972). Mode of action of a Staphylococcus epidermidis bacteriocin. Antimicrobial agents and chemotherapy, 2(6), 456-463. Jiang, H., Tang, X., Zhou, Q., Zou, J., Li, P., Breukink, E., \& Gu, Q. (2018) Plantaricin NC8 from Lactobacillus plantarum causes cell membrane disruption to 
Micrococcus luteus without targeting lipid II. Applied microbiology and biotechnology, 102(17), 7465-7473.

Jozala, A. F., Novaes, L. C. L., \& Junior, A. P. (2015). Nisin, Concepts, Compounds and the Alternatives of Antibacterials. Inmunology and Microbiology, 5-103

Kato, F., Ogata, S., \& Hongo, M. (1977). Action of an Inducible Bacteriocin Clostocin $\mathrm{O}$ on the Macromolecular Syntheses of Clostridium saccharoperbutylacetonicum. Agricultural and Biological Chemistry, 41(10), 1883-1888.

Kaur, S., \& Kaur, S. (2015). Bacteriocins as potential anticancer agents. Frontiers in pharmacology, 6, 272. https://doi.org/10.3389/fphar.2015.00272

Kaushik, R., \& Arora, S. (2017). Effect of calcium and vitamin D 2 fortification on physical, microbial, rheological and sensory characteristics of yoghurt. International Food Research Journal, 24(4).

Kaushik, R., Sachdeva, B., \& Arora, S. (2017). Effect of calcium and vitamin D2 fortification on quality characteristics of dahi. International Journal of Dairy Technology, 70(2), 269-276.

Khalaf, H., Nakka, S. S., Sandén, C., Svärd, A., Hultenby, K., Scherbak, N., ... \& Bengtsson, T. (2016). Antibacterial effects of Lactobacillus and bacteriocin PLNC8 $\alpha \beta$ on the periodontal pathogen Porphyromonas gingivalis. BMC microbiology, 16(1), 1-11. https://doi.org/10.1186/s12866-016-0810-8

Klaenhammer, T. R. (1993). Genetics of bacteriocins produced by lactic acid bacteria. FEMS microbiology reviews, 12(1-3), 39-85.

Klein, A., Wojdyla, J. A., Joshi, A., Josts, I., McCaughey, L. C., Housden, N. G. \& Kleanthous, C. (2016). Structural and biophysical analysis of nuclease protein antibiotics. Biochemical Journal, 473(18), 2799-2812. Doi 10.1042/BCJ20160544

Konisky, J. (1982). Colicins and other bacteriocins with established modes of action. Annual Reviews in Microbiology, 36(1), 125-144.

Krämer, J., \& Brandis, H. (1975). Mode of action of two Streptococcus faecium bacteriocins. Antimicrobial agents and chemotherapy, 7(2), 117-120.

Kumari S, Sharma S, Kaundal K. (2018). Production, purification and efficacy of bacteriocin isolated from natural lactic acid fermentation of wild Himalayan fig fruit. Journal of Pure and Applied Microbiology. 12(2): 879-885.

Kumariya, R., Garsa, A. K., Rajput, Y. S., Sood, S. K., Akhtar, N., \& Patel, S. (2019). Bacteriocins: Classification, synthesis, mechanism of action and resistance development in food spoilage causing bacteria. Microbial pathogenesis, 128, 171177 .

Lagos, R., Tello, M., Mercado, G., García, V., \& Monasterio, O. (2009) Antibacterial and antitumorigenic properties of microcin E492, a pore-forming bacteriocin. Current pharmaceutical biotechnology, 10(1), 74-85.

Lajis, A. F. B. (2020). Biomanufacturing process for the production of bacteriocins from Bacillaceae family. Bioresources and Bioprocessing, 7(1), 1-26. https://doi.org/10.1186/s40643-020-0295-Z

Law, D. J., \& Dajani, A. S. (1978). Interactions between Neisseria sicca and viridin $\mathrm{B}$, a bacteriocin produced by Streptococcus mitis. Antimicrobial agents and chemotherapy, 13(3), 473-478.

Li, J., Aroutcheva, A. A., Faro, S., \& Chikindas, M. L. (2005). Mode of action of lactocin 160, a bacteriocin from vaginal Lactobacillus rhamnosus. Infectious diseases in obstetrics and gynecology, 13(3), 135.

Liu, G., Song, Z., Yang, X., Gao, Y., Wang, C., \& Sun, B. (2016). Antibacterial mechanism of bifidocin $\mathrm{A}$, a novel broad-spectrum bacteriocin produced by Bifidobacterium animalis BB04. Food Control, 62, 309-316.

Lopes, J. L. S., Nobre, T. M., Siano, Á., Humpola, V., Bossolan, N. R., Zaniquelli, M. E., ... \& Beltramini, L. M. (2009). Disruption of Saccharomyces cerevisiae by Plantaricin 149 and investigation of its mechanism of action with biomembrane model systems. Biochimica et Biophysica Acta (BBA)-Biomembranes, 1788(10), 2252-2258

Lopez-Lara, I., Gálvez, A., Martinez-Bueno, M., Maqueda, M., \& Valdivia, E. (1991). Purification, characterization, and biological effects of a second bacteriocin from Enterococcus faecalis ssp. liquefaciens S-48 and its mutant strain B-48-28. Canadian journal of microbiology, 37(10), 769-774.

Maftah, A., Renault, D., Vignoles, C., Héchard, Y., Bressollier, P., Ratinaud, M. H., ... \& Julien, R. (1993). Membrane permeabilization of

Listeria monocytogenes and mitochondria by the bacteriocin mesentericin Y105. Journal of bacteriology, 175(10), 3232-3235.

Majeed H, Lampert A, Ghazaryan L, Gillor O. (2013). The weak shall inherit: bacteriocin-mediated interactions in bacterial populations. PloS one. 8:e63837.

Marciset, O., Jeronimus-Stratingh, M. C., Mollet, B., \& Poolman, B. (1997)

Thermophilin 13, a nontypical antilisterial poration complex bacteriocin, that functions without a receptor. Journal of Biological Chemistry, 272(22), 14277 14284.

MARCOS BALCIUNAS, E., CASTILLO MARTINEZ, F. A., DIMITROV TODOROV, S., GOMBOSSY DE MELO FRANCO, B. D., \& CONVERTI, A (2013). Novel biotechnological applications of bacteriocins: A review. Food control, 32(1), 134-142.

Martínez, B., Böttiger, T., Schneider, T., Rodríguez, A., Sahl, H. G., \&

Wiedemann, I. (2008). Specific interaction of the unmodified bacteriocin Lactococcin 972 with the cell wall precursor lipid II.
Mayr-Harting, A., Hedges, A. J., \& Berkeley, R. C. W. (1972). Chapter VII methods for studying bacteriocins. In Methods in microbiology (Vol. 7, pp. 315 422). Academic Press.

McAuliffe, O., Ryan, M. P., Ross, R. P., Hill, C., Breeuwer, P., \& Abee, T. (1998) Lacticin 3147, a broad-spectrum bacteriocin which selectively dissipates the membrane potential. Applied and Environmental Microbiology, 64(2), 439-445.

McEntire, J. C., Carman, G. M., \& Montville, T. J. (2004). Increased ATPase activity is responsible for acid sensitivity of nisin-resistant Listeria monocytogenes ATCC 700302. Applied and environmental microbiology, 70(5), 2717-2721.

Michalek, M., Sönnichsen, F. D., Wechselberger, R., Dingley, A. J., Hung, C. W., Kopp, A., ... \& Leippe, M. (2013). Structure and function of a unique pore-forming protein from a pathogenic acanthamoeba. Nature chemical biology, 9(1), 37-42.

Mittal, M., Thakur, A., Kaushik, R., \& Chawla, P. (2020). Physicochemical properties of Ocimum sanctum enriched herbal fruit yoghurt. Journal of Food Processing and Preservation, e14976. https://doi.org/10.1111/jfpp.14976.

Mo Moll, G. N., Roberts, G. C., Konings, W. N., \& Driessen, A. J. (1996) Mechanism of lantibiotic-induced pore-formation. Antonie van Leeuwenhoek, 69(2), 185-191. https://doi.org/10.1007/BF00399423

Mokoena, M. P. (2017). Lactic acid bacteria and their bacteriocins: classification, biosynthesis and applications against uropathogens: a minireview. Molecules, 22(8), 1255.

Moll, G. N., Roberts, G. C., Konings, W. N., \& Driessen, A. J. (1996). Mechanism of lantibiotic-induced pore-formation. Antonie van Leeuwenhoek, 69(2), 185-191. Mora, L., Moncoq, K., England, P., Oberto, J., \& de Zamaroczy, M. (2015). The stable interaction between signal peptidase LepB of Escherichia coli and nuclease bacteriocins promotes toxin entry into the cytoplasm. Journal of Biological Chemistry, 290(52), 30783-30796.

Mossie, K. G., Jones, D. T., Robb, F. T., \& Woods, D. R. (1979). Characterization and mode of action of a bacteriocin produced by a Bacteroides fragilis strain. Antimicrobial Agents and Chemotherapy, 16(6), 724-730.

Mossie, K. G., Robb, F. T., Jones, D. T., \& Woods, D. R. (1981). Inhibition of ribonucleic acid polymerase by a bacteriocin from Bacteroides fragilis. Antimicrobial Agents and Chemotherapy, 20(4), 437-442.

Münch, D., Müller, A., Schneider, T., Kohl, B., Wenzel, M., Bandow, J. E., ... \& Sahl, H. G. (2014). The lantibiotic NAI-107 binds to bactoprenol-bound cell wall precursors and impairs membrane functions. Journal of Biological Chemistry, 289(17), 12063-12076.

Nettles, C. G., \& Barefoot, S. F. (1993). Biochemical and genetic characteristics of bacteriocins of food-associated lactic acid bacteria. Journal of food Protection, 56(4), 338-356.

Nilsen, T., Nes, I. F., \& Holo, H. (2003). Enterolysin A, a cell wall-degrading bacteriocin from Enterococcus faecalis LMG 2333. Applied and environmental microbiology, 69(5), 2975-2984

Nissen-Meyer, J., Holo, H., Håvarstein, L. S., Sletten, K., \& Nes, I. F. (1992). A novel lactococcal bacteriocin whose activity depends on the complementary action of two peptides. Journal of bacteriology, 174(17), 5686-5692.

Ogawa, T. (2016). tRNA-targeting ribonucleases: molecular mechanisms and insights into their physiological roles. Bioscience, biotechnology, and biochemistry, 80(6),

http://dx.doi.org/10.1080/09168451.2016.1148579

Omersa, N., Podobnik, M., \& Anderluh, G. (2019). Inhibition of pore-forming proteins. Toxins, 11(9), 545.

Oscáriz, J. C., \& Pisabarro, A. G. (2001). Classification and mode of action of membrane-active bacteriocins produced by gram-positive bacteria. International Microbiology, 4(1), 13-19.

Ostolaza, H., González-Bullón, D., Uribe, K. B., Martín, C., Amuategi, J., \& Fernandez-Martínez, X. (2019). Membrane Permeabilization by

Pore-Forming RTX Toxins: What Kind of Lesions Do These Toxin Form?. Toxins, 11(6), 354. https://doi.org/10.3390/toxins11060354

Paiva, A. D., Breukink, E., \& Mantovani, H. C. (2011). Role of lipid II and membrane thickness in the mechanism of action of the lantibiotic bovicin HC5. Antimicrobial agents and chemotherapy, 55(11), 5284-5293.

Panchal, R. G., Smart, M. L., Bowser, D. N., Williams, D. A., \& Petrou, S. (2002) Pore-forming proteins and their application in biotechnology. Current pharmaceutical biotechnology, 3(2), 99-115.

Pangsomboon, K., Kaewnopparat, S., Pitakpornpreecha, T., \& Srichana, T. (2006) Antibacterial activity of a bacteriocin from Lactobacillus paracasei HL32 against Porphyromonas gingivalis. Archives of oral biology, 51(9), 784-793.

Parada, J. L., Caron, C. R., Medeiros, A. B. P., \& Soccol, C. R. (2007). Bacteriocins from lactic acid bacteria: purification, properties and use as biopreservatives. Brazilian archives of Biology and Technology, 50(3), 512-542 https://doi.org/10.1590/S1516-89132007000300018

Pei, J., Yue, T., \& Yuan, Y. (2014). Control of Alicyclobacillus acidoterrestris in fruit juices by a newly discovered bacteriocin. World Journal of Microbiology and Biotechnology, 30(3), 855-863.

Pirzada, Z. Z., \& Ali, S. A. (2004). Production of physicochemical characterization of bacteriocins like inhibitory substances from marine bacterium ZM18. Pakistan Journal of Biological Sciences, 7(12), 2026-2030. 
Preciado, G. M., Michel, M. M., Villarreal-Morales, S. L., Flores-Gallegos, A. C. Aguirre-Joya, J., Morlett-Chávez, J., ... \& Rodríguez-Herrera, R. (2016) Bacteriocins and its use for multidrug-resistant bacteria control. Antibiot Resist, 329-49.

Prince, A., Sandhu, P., Ror, P., Dash, E., Sharma, S., Arakha, M., ... \& Saleem, M (2016). Lipid-II independent antimicrobial mechanism of nisin depends on its crowding and degree of oligomerization. Scientific reports, 6(1), 1-15. https://doi.org/10.1038/srep37908

PUGSLEY, A. P., GOLDZAHL, N., \& BARKER, R. M. (1985). Colicin E2 production and release by Escherichia coli K12 and other Enterobacteriaceae. Microbiology, 131(10), 2673-2686.

Rai, P., He, F., Kwang, J., Engelward, B. P., \& Chow, V. T. (2016). Pneumococcal pneumolysin induces DNA damage and cell cycle arrest. Scientific reports, $6(1)$ 1-12. https://doi/org/10.1038/srep22972

Ramu, R., Shirahatti, P. S., Devi, A. T., \& Prasad, A. (2015). Bacteriocins and their applications in food preservation. Critical reviews in food science and nutrition, 0 0. DOI: 10.1080/10408398.2015.1020918

Reddy, K. V. R., Yedery, R. D., \& Aranha, C. (2004). Antimicrobial peptides: premises and promises. International journal of antimicrobial agents, 24(6), 536547.

Reeves, P. (1965). The bacteriocins. Bacteriological reviews, 29(1), 24

Reeves, P. (1972). Mode of Action-The Adsorption of Bacteriocins. In The Bacteriocins (pp. 46-59). Springer, Berlin, Heidelberg.

Riley, M. A., \& Gordon, D. M. (1999). The ecological role of bacteriocins in bacterial competition. Trends in microbiology, 7(3), 129-133.

Riley, M. A., \& Wertz, J. E. (2002). Bacteriocins: evolution, ecology, and application. Annual Reviews in Microbiology, 56(1), 117-137.

Roces, C., Rodríguez, A., \& Martínez, B. (2012). Cell wall-active bacteriocins and their applications beyond antibiotic activity. Probiotics and antimicrobial proteins, 4(4), 259-272.

Rosa, C. M., Franco, B. D. G. M., Montville, T. J., \& Chikindas, M. L. (2002) Purification and mechanistic action of a bacteriocin produced by a Brazilian sausage isolate, Lactobacillus sake 2a. Journal of food safety, 22(1), 39-54.

Schaller, K., \& Nomura, M. (1976). Colicin E2 is DNA endonuclease. Proceedings of the National Academy of Sciences, 73(11), 3989-3993

Scherer, K. M., Spille, J. H., Sahl, H. G., Grein, F., \& Kubitscheck, U. (2015). The lantibiotic nisin induces lipid II aggregation, causing membrane instability and vesicle budding. Biophysical journal, 108(5), 1114-1124

Sharma, N., Attri, A., \& Gautam, N. (2009). Purification and Characterization of Bacteriocin Like Substance Produced from Bacillus lentus with

Perspective of a New Biopreservative for Food Preservation. Biological Sciences - PJSIR, 52(4).

Sharma, S. S., Kaushik, R., Sharma, P., Sharma, R., Thapa, A., \& Kp, I. K. (2016) Antimicrobial activity of herbs against Yersinia enterocolitica and mixed microflora. The Annals of the University Dunarea de Jos of Galati. Fascicle VIFood Technology, 40(2), 118-134.

Sharma, S., Kaushik, R., Sharma, S., Chuhan, P., \& Kumar, N. (2016). Effect of herb extracts on growth of probiotic cultures. Indian Journal of Dairy Science, 69(3).

Sharp, C., Bray, J., Housden, N. G., Maiden, M. C., \& Kleanthous, C. (2017) Diversity and distribution of nuclease bacteriocins in bacterial genomes revealed using Hidden Markov Models. PLoS computational biology, 13(7), e1005652. https://doi.org/10.1371/journal.pcbi.1005652

Shin, J. M., Gwak, J. W., Kamarajan, P., Fenno, J. C., Rickard, A. H., \& Kapila Y. L. (2016). Biomedical applications of nisin. Journal of applied microbiology, 120(6), 1449-1465.

Sing, R. (2021). Sensory and nutritional qualities of multi-grain cookies supplemented with different level of rice bran. Food and Agriculture Spectrum Journal, 2(01), 5-7.

Singh, R., Mehra, R., Walia, A., Gupta, S., Chawla, P., kumar, H., ... \& Kumar, N. (2021). Colorimetric sensing approaches based on silver nanoparticles aggregation for determination of toxic metal ions in water sample: a review. International Journal of Environmental Analytical Chemistry, 1-16.

Singh, T., Pandove, G., \& Arora, M. (2013). Bacteriocins. Mini Review Journal of Biotechnological Sciences, 1(2), 73-75.

Sun, Z., Wang, X., Zhang, X., Wu, H., Zou, Y., Li, P., ... \& Wang, D. (2018). Class III bacteriocin Helveticin-M causes sublethal damage on target cells through impairment of cell wall and membrane. Journal of Industrial Microbiology and Biotechnology, 45(3), 213-227.

SUR LA PLURALITE DES RECEPTEURS DANTIBIOSE DE ECOLI. COMPTES RENDUS DES SEANCES DE LA SOCIETE DE BIOLOGIE ET DE SES FILIALES, 140(12), 1189-1191.

Suzuki, M., Yamamoto, T., Kawai, Y., Inoue, N., \& Yamazaki, K. (2005). Mode of action of piscicocin CS526 produced by Carnobacterium piscicola CS526. Journal of applied microbiology, 98(5), 1146-1151

Tagg, J. R., Dajani, A. S., Wannamaker, L. W., \& Gray, E. D. (1973). Group A streptococcal bacteriocin: production, purification, and mode of action. The $\begin{array}{llll}\text { Journal of experimental medicine, 138(5), } & 1168\end{array}$ https://doi.org/10.1084/jem.138.5.1168
Tahara, T., Oshimura, M., Umezawa, C., \& Kanatani, K. (1996). Isolation, partial characterization, and mode of action of acidocin J1132, a two-component bacteriocin produced by Lactobacillus acidophilus JCM 1132. Applied and Environmental Microbiology, 62(3), 892-897.

Todorov, S. D., \& Dicks, L. M. T. (2005). Lactobacillus plantarum isolated from molasses produces bacteriocins active against Gram-negative bacteria. Enzyme and Microbial Technology, 36(2-3), 318-326.

Tol, M. B., Morales Angeles, D., \& Scheffers, D. J. (2015). In vivo cluster formation of nisin and Lipid II is correlated with membrane depolarization. Antimicrobial agents and chemotherapy, 59(6), 3683-3686.

Tolinački, M., Kojić, M., Lozo, J., Terzić-Vidojević, A., Topisirović, L., \& Fira D. (2010). Characterization of the bacteriocin-producing strain

Lactobacillus paracasei subsp. paracasei BGUB9. Archives of Biological Sciences, 62(4), 889-899.

Torreblanca, M., Meseguer, I., \& Rodriguez-Valera, F. (1990). Effects of halocin H6 on the morphology of sensitive cells. Biochemistry and Cell Biology, 68(1) 396-399.

Torrebranca, M., Meseguer, I., \& Ventosa, A. (1995). Bacteriocin Biology. Letters in Applied Microbiology, 19, 201-205.

Trivedi, D., Jena, P. K., \& Seshadri, S. (2014). Colicin E2 Expression in Lactobacillus brevis DT24, a vaginal probiotic isolate, against uropathogenic Escherichia coli. International Scholarly Research Notices, 2014 https://doi.og/10.1155/2014/869610

Tumbarski, Y., Lante, A., \& Krastanov, A. (2018). Immobilization of bacteriocins from lactic acid bacteria and possibilities for application in food biopreservation. The Open Biotechnology Journal,12(1). DOI: $10.2174 / 1874070701812010025$

Tweten, R. K., Hotze, E. M., \& Wade, K. R. (2015). The unique molecular choreography of giant pore formation by the cholesterol-dependent cytolysins of Gram-positive bacteria. Annual review of microbiology, 69, 323-340.

Upreti, G. C., \& Hinsdill, R. D. (1975). Production and mode of action of lactocin 27: bacteriocin from a homofermentative Lactobacillus. Antimicrobial agents and chemotherapy, 7(2), 139-145.

Uratani, Y. O. S. H. I. H. I. K. O., \& Hoshino, T. O. S. H. I. M. I. T. S. U. (1984) Pyocin R1 inhibits active transport in Pseudomonas aeruginosa and depolarizes membrane potential. Journal of bacteriology, 157(2), 632-636.

van Kraaij, C., Breukink, E., Noordermeer, M. A., Demel, R. A., Siezen, R. J., Kuipers, O. P., \& de Kruijff, B. (1998). Pore formation by nisin involves translocation of its C-terminal part across the membrane. Biochemistry, 37(46), 16033-16040

Vögele, M., Bhaskara, R. M., Mulvihill, E., van Pee, K., Yildiz, Ö., Kühlbrandt, W., ... \& Hummer, G. (2019). Membrane perforation by the pore-forming toxin pneumolysin. Proceedings of the National Academy of Sciences, 116(27), 1335213357. https://doi.org/10.1073/pnas .1904304116

Walker, D., Mosbahi, K., Vankemmelbeke, M., James, R., \& Kleanthous, C. (2007). The role of electrostatics in colicin nuclease domain translocation into bacterial cells. Journal of Biological Chemistry, 282(43), 31389-31397.

Wayah, S. B., \& Philip, K. (2018). Pentocin MQ1: a novel, broad-spectrum, poreforming bacteriocin from Lactobacillus pentosus CS2 with quorum sensing regulatory mechanism and biopreservative potential. Frontiers in microbiology, 9 , 564. Doi: 10.3389/fmicb.2018.00564.

Wiedemann, I., Benz, R., \& Sahl, H. G. (2004). Lipid II-mediated pore formation by the peptide antibiotic nisin: a black lipid membrane study. Journal of bacteriology, 186(10), 3259-3261.

Wu, C., Biswas, S., Garcia De Gonzalo, C. V., \& Van Der Donk, W. A. (2018). Investigations into the mechanism of action of sublancin. ACS infectious diseases, 5(3), 454-459.

Yang, S. C., Lin, C. H., Sung, C. T., \& Fang, J. Y. (2014). Antibacterial activities of bacteriocins: application in foods and pharmaceuticals. Frontiers in microbiology, 5, 241. Doi: 10.3389/fmicb.2014.00241. PMID: 24904554.

Yoneyama, F., Imura, Y., Ohno, K., Zendo, T., Nakayama, J., Matsuzaki, K., \& Sonomoto, K. (2009). Peptide-lipid huge toroidal pore, a new antimicrobial mechanism mediated by a lactococcal bacteriocin, lacticin Q. Antimicrobial agents and chemotherapy, 53(8), 3211-3217.

Zamfir, M., \& Grosu-Tudor, S. (2009). Impact of stress conditions on the growth of Lactobacillus acidophilus IBB 801 and production of acidophilin 801. The Journal of general and applied microbiology, 55(4), 277-282.

Zamfir, M., Brezeanu, A., \& De Vuyst, L. (2007). Bactericidal effect of acidophilin 801, a bacteriocin produced by Lactobacillus acidophilus IBB 801. Romanian Biotechnological Letters, 12, 3521-3531.

Zheng, J., Gänzle, M. G., Lin, X. B., Ruan, L., \& Sun, M. (2015). Diversity and dynamics of bacteriocins from human microbiome. Environmental microbiology, 17(6), 2133-2143.

Zhou, K., Zhou, W., Li, P., Liu, G., Zhang, J., \& Dai, Y. (2008). Mode of action of pentocin 31-1: an antilisteria bacteriocin produced by Lactobacillus pentosus from Chinese traditional ham. Food Control, 19(8), 817-822. 